\title{
13: $112808106-112822346$
}

National Cancer Institute

\section{Source}

National Cancer Institute. 13: 112808106-112822346. NCI Thesaurus. Code C42236.

Physical location of F7_Gene 